\title{
Revista LETRA S
}

Publicação do Curso de Letras do Setor de Ciências Humanas, Letras e Artes da Universidade Federal do Paraná.

A sugestão de tema para o próximo número é, para a área dos Estudos Literários, a INTERTEXTUALIDADE. Para a área dos Estudos Linguiisticos gostaríamos de receber trabalhos que, mais do que soluções, apresentassem PROBLEMAS, cujas soluções correntes são insatisfatórias ou para os quais ainda não se apresentaram soluções.

Apreciaremos as colaborações enviadas até $1 .^{\circ}$ de março de 1991.

O Editor 